\title{
Enteral Nutrition Supplemented with Transforming Growth Factor- $\beta$, Colostrum, Probiotics, and Other Nutritional Compounds in the Treatment of Patients with Inflammatory Bowel Disease
}

\author{
John K. Triantafillidis ${ }^{1, *}$, Maria Tzouvala ${ }^{2}$ and Eleni Triantafyllidi ${ }^{1}$ \\ 1 “Metropolitan General” Hospital, ZC 15562 Holargos, Greece; eltriant@yahoo.gr \\ 2 Department of Gastroenterology "St Panteleimon" General Hospital, ZC 18454 Nicea, Greece; \\ tzouvalam@gmail.com \\ * Correspondence: jktrian@gmail.com
}

Received: 21 March 2020; Accepted: 8 April 2020; Published: 10 April 2020 updates

\begin{abstract}
Enteral nutrition seems to play a significant role in the treatment of both adults and children with active Crohn's disease, and to a lesser degree in the treatment of patients with active ulcerative colitis. The inclusion of some special factors in the enteral nutrition formulas might increase the rate of the efficacy. Actually, enteral nutrition enriched in Transforming Growth Factor- $\beta$ reduced the activity index and maintained remission in patients with Crohn's disease. In addition, a number of experimental animal studies have shown that colostrum exerts a significantly positive result. Probiotics of a special type and a certain dosage could also reduce the inflammatory process in patients with active ulcerative colitis. Therefore, the addition of these factors in an enteral nutrition formula might increase its effectiveness. Although the use of these formulas is not supported by large clinical trials, it could be argued that their administration in selected cases as an exclusive diet or in combination with the drugs used in patients with inflammatory bowel disease could benefit the patient. In this review, the authors provide an update on the role of enteral nutrition, supplemented with Transforming Growth Factor- $\beta$, colostrum, and probiotics in patients with inflammatory bowel disease.
\end{abstract}

Keywords: enteral nutrition; TGF- $\beta$; colostrum; probiotics; Crohn's disease; ulcerative colitis; inflammatory bowel disease

\section{Introduction}

Enteral nutrition (EN) can reduce Crohn's disease (CD) activity and maintain remission in both children and adults [1,2]. According to the international guidelines, nutritional support using orally administered liquid formulas should be considered for $C D$ patients, serious cases of ulcerative colitis (UC), in combination with steroids in undernourished individuals, in cases of steroid intolerance, and in patients with stenosis of the small intestine [1-4]. Transforming Growth Factor- $\beta$ (TGF $\beta$ ), a polypeptide present in both human and bovine milk, has been shown to play an important role in the development of immune tolerance and the prevention of autoimmunity, being concurrently an inhibitor of intestinal epithelial cell growth and a stimulator of intestinal epithelial cell differentiation [5].

Studies concerning the administration of EN formulas containing TGF $\beta$ in both adults and children with active and inactive $C D$ have been previously published, although their promising results were based on a small number of patients [6-8]. Colostrum is the first milk produced after birth, being rich in a number of bioactive molecules, including growth factors. It has been experimentally used in rats, and the results of its administration were encouraging $[9,10]$, although, again, there is a lack of 
controlled clinical studies. Finally, probiotics of a special type and dosage could in fact reduce the inflammatory process in patients with active ulcerative colitis UC [11-13].

During the last two decades, industry efforts resulted in the production of food containing TGF $\beta$ and other molecules that have biological activities for patients with inflammatory bowel disease IBD. The hope is that the addition of these biological molecules in the same EN formula might increase the beneficial effect expected from the administration of EN not containing these factors.

In this review the authors analyze the theoretical basis of adding TGF $\beta$, colostrum, probiotics, and other bioactive compounds, including flavonoids, short chain fatty acids, and bioactive peptides, in an EN formula. Then, they try to critically evaluate the available data regarding the effectiveness of this formula in patients with IBD.

\section{Tranforming Growth Factor- $\beta$}

TGF $\beta$ is a cytokine produced by all white blood cell lineages, belonging to the TGF superfamily, which is a family of proteins named after the first member TGF $\beta 1$. It includes three different isoforms and other signaling proteins. It consists of ligands and receptors that all signal through downstream mediators, termed the Smads. Secreted TGF $\beta$ is a latent complex, proteolytically cleaved in the extracellular space resulting in the release of TGF $\beta$ dimmer allowing TGF $\beta$ to bind to cell surface receptors [14,15].

It is present in both human and bovine milk in high concentrations $(20-40 \mathrm{mg} / \mathrm{L}$ and $1-2 \mathrm{mg} / \mathrm{L}$ respectively). The amount of TGF $\beta$ being present in milk could maintain the gastrointestinal integrity in suckling human neonates.

Active TGF $\beta$ regulates cell adhesion and apoptosis through the TGF $\beta$ signaling pathway. It also plays an important role in the development of immune tolerance and the prevention of autoimmunity, concurrently being an inhibitor of intestinal epithelial cell growth and a stimulator of intestinal epithelial cell differentiation. It is a potent chemo-attractant for neutrophils and stimulates epithelial cell migration at wound sites, thus facilitating wound repair. TGF $\beta$ is the master regulator to drive fibrosis and angiogenesis in the intestine [16]. TGF $\beta$ plays an important role in the function of a number of immune cells, including $\mathrm{T}$ and B lymphocytes, macrophages, as well as in the cell cycle [17]. Among its key functions is the regulation of inflammatory processes, particularly in the gut $[18,19]$. TGF $\beta$ also plays a crucial role in stem cell differentiation, as well as in T cell regulation and differentiation [20]. Neutralization of TGF $\beta$ in vitro inhibits the differentiation of helper $T$ cells into $T_{h} 17$ cells.

TGF $\beta$ inhibits B cell proliferation via the induction of the transcription factor Id 3 , blocks B cell activation and promotes class switching Immunoglobulin A ( $\operatorname{IgA})$ in both human and mouse B cells. TGF $\beta$, also, has an inhibitory function for antibody production [21] and induces the apoptosis of immature or resting B cells. It stimulates resting monocytes and inhibits activated macrophages, acting as a chemoattractant for monocytes [22] and downregulates inflammatory cytokine production by monocytes and macrophages through the inhibition of NF- $\mathrm{kB}$ [23].

TGF $\beta$ promotes IgA production as well as oral tolerance towards cow's milk. Low levels of IgA have been observed in the colostrum and breast milk of mothers of offspring who experienced a cow's milk allergy [24]. Therefore, TGF $\beta$ plays an important role in maintaining tolerance against self antigens and antigens derived from food, commensal bacteria, and fetal alloantigens [14]. It also plays a crucial role in the regulation of the cell cycle by blocking progress through suppressing the expression of c-myc, a gene which is involved in G1 cell cycle progression [25].

\section{TGF $\beta$ and Inflammatory Bowel Disease}

TGF $\beta$ is involved in various chronic inflammatory disorders, including IBD. It has been shown long since that TGF $\beta$ and its receptors were increased in intestinal cells of patients with IBD, especially in CD patients [26], a fact confirmed in experimental animal models [16]. TGF $\beta$ functions by binding to two receptors, type I subtype ALK5 and type II, which are concomitantly required for signal transduction. TGF $\beta$, also, binds to its type III receptor (betaglycan), creating a heteromeric complex 
with TGF $\beta$ type II receptor. Binding of the ligands to type II receptors activates the type I receptor. The activated TGF $\beta$ receptors phosphorylate Smad2 and Smad3 heterodimer subsequently interacting with Smad4. The Smad2/3-Smad4 complex translocates from the cytosol to the nucleus and binds to other DNA-binding co-factors regulating specific TGF $\beta$ target genes, including fibronectin and collagen [27]. The concomitant over-expression of TGF $\beta$ and their signaling receptors in CD means that these regulatory molecules might play a role in the pathophysiology of $\mathrm{CD}$. The activation of TGF $\beta$-mediated pathways might promote the repair of mucosal injury by enhancing the process of reepithelization, concurrently promoting, however, extracellular matrix generation, intramural fibrosis and intestinal obstruction [28]. Myofibroblasts derived from smooth muscle cells in chronic inflammatory situations, can increase fibrosis in IBD through the production of collagen and matrix metalloproteinases due to stimulation of TGF- $\beta$ [29].

Antibodies inhibiting the binding of the ligand to the receptor and antisense oligonucleotides resulting in the reduction of the expression of TGF $\beta$, such as Smad6 and Smad7, have been developed [30,31]. The inhibition of Smad7 using antisense oligonucleotides decreased inflammation in an animal model of TNBS colitis [32] and improved the clinical activity of patients with CD [33] The orally administered antisense oligonucleotide of Smad7 (mongersen) showed a clinical efficacy in CD patients, although high doses induced bowel obstruction caused by TGF $\beta$ signaling promoting fibrosis [34]. Another potent proinflammatory cytokine involved in TGF- $\beta$ signaling is IFN- $\gamma$, a cytokine that inhibits the TGF $\beta$-induced phosphorylation of Smad 3 and the activation of TGF $\beta$ genes by inducing the expression of Smad7 [35].

The critical role of TGF $\beta$ in the development and homeostasis of intestinal immunity and the CNS in humans was recently stressed by Kotlarz et al., who described three individuals with biallelic loss-of-function mutations in the TGF $\beta$ gene presented with severe infantile IBD and CNS disease [36].

\section{Colostrum in Health and Disease}

Colostrum should be defined as the milk produced in the first $48 \mathrm{~h}$ after birth. It is rich in a wide range of antimicrobial peptides, immune-regulating components and growth factors harboring anti-inflammatory and immuno-modulatory properties. Human breast milk is rich in nutrients, hormones, growth factors and immunoactive molecules with anti-inflammatory and immunomodulatory properties, which can influence the growth, development and immune status of the infant [37]. The pivotal functions of colostrum are to provide essential nutritional components, reinforce natural defenses, modulate intestinal microflora and immune responses, and promote the growth, maturation and repair of many tissues [38].

During breast feeding, all the isoforms of the TGF $\beta$ are produced, the majority being TGF $\beta 2$ [39]. The levels of this cytokine range between 0.1 and $13.3 \mu \mathrm{g} / \mathrm{L}$ in term colostrum and between 1.4 and $43 \mu \mathrm{g} / \mathrm{L}$ in preterm colostrum. These levels decrease along the lactation period with concentrations of $0.4-2.8 \mu \mathrm{g} / \mathrm{L}$ in term and $0.9-6.3 \mu \mathrm{g} / \mathrm{L}$ in preterm mature milk [40].

The bioactive substances present in milk and colostrum that might be useful in a number of pathological situations, are shown in Table 1. It is important to bear in mind that many of the factors present in milk and colostrum, e.g., Epidermal Growth Factor (EGF), TGF $\alpha$, TGF $\beta$, amphiregulin, betacellulin, and heparin-binding EGF-like peptides, are also produced in the gut, explaining, at least in part, why colostrum promotes the repair of the gut mucosa [41]. Colostrum whey proteins have been administered at a dose of $30 \mathrm{~g} / \mathrm{d}$ for 6 months in humans without any kind of side-effects [42]. 
Table 1. Trophic and bioactive factors in colostrum and milk.

\begin{tabular}{c}
\hline Antioxidants \\
$\alpha$-Carotene \\
$\beta$-Carotene \\
Lycopene \\
Retinol \\
$\alpha$-tocopherol \\
$\gamma$-tocoferol \\
\hline Nonpeptide trophic factors \\
Glutamine \\
Polyamines \\
Nucleotides \\
$\bullet \quad$ Hormones \\
Cytokines \\
Growth factors \\
\hline Epidermal Growth Factor (EGF) \\
Transforming Growth Factor-a (TGFa) \\
Transforming Growth Factor- $\beta$ family (TGF $\beta)$ \\
Platelet-derived Growth Factor \\
Vascular Endothelial Growth Factor (VEGF) \\
Growth Hormone and its Releasing Factor \\
Hepatocyte Growth Factor (HGF) \\
Neuronal Growth Factors \\
Insulin-Like Growth Factor (IGF) Superfamily \\
\hline
\end{tabular}

Colostrum is rich in biologically active molecules that have specific functions in the physiology of the digestive system. It has been shown that colostrum induces epithelial regeneration via the stimulation of cellular proliferation and differentiation. Colostrum growth factors and lactoferrin could modulate the function of intestinal cells [43]. Orally administered bovine Lactoferrin inhibits vascular EGF-induced angiogenesis in normal rats [44]. Furthermore, colostrum inhibits the expression of inflammatory genes following invasion by enteric pathogens, reduces the inflammatory cytokines (IL-1 $\beta$, IL-8, and TNF $\alpha$ ) and inhibits the NF- $\mathrm{kB}$ pathway [45]. The oligosaccharides (fructo-oligosaccharides, beta-galactooligosaccharides, gangliosides, and nucleosides) present in bovine milk selectively stimulate the growth of beneficial bacteria acting as prebiotics [46]. It seems that colostrum is able to preserve the intestinal microbiota, which enforces the mucosal barrier, thus reducing the inflammatory reactions. Beneficial Gram negative bacteria can, also, reduce the cell surface expression level of the LPS receptor complex and, subsequently, the activation of the TLR4 signaling pathway. Based on these data, it might be argued that bovine colostrum may reduce the side-effects of drugs used in the treatment of IBD, although this assumption needs to be confirmed in clinical trials. Bovine colostrum contains high levels of immunoglobulins that can reduce antigenic stimulation derived from gut endotoxins (LPS), thus improving the state of tolerance and reducing the risk of bacterial translocation [47]. Finally, colostrum can prevent gastrointestinal infections in infants, as it has been noticed that infants on a formulated diet are more susceptible to infectious diarrhea compared to breast-feeding infants [48].

\subsection{Clinical Studies of Colostrum in Patients with IBD}

While several studies have evaluated the effects of colostrum administration in the prevention and treatment of various gastrointestinal disorders in different animal species and humans [49-53], studies concerning the clinical use of bovine colostrum in IBD are still limited and controversial [54]. In a small study, Khan et al. investigated the role of bovine colostrum in 14 patients with mild to moderately severe distal colitis. Patients received colostrum enemas $(100 \mathrm{~mL}$ of $10 \%$ solution, eight patients) or placebo (albumin solution, six patients) twice daily for 4 weeks in conjunction with their regular treatment with mesalazine $(1.6 \mathrm{~g} / \mathrm{d})$. After 4 weeks, the colostrum group had a mean 
reduction in symptom score of -2.9 , whereas in the placebo group the corresponding feature was +0.5 . The histological score improved in five of eight patients in the colostrum group. This small encouraging study has not been, so far, repeated, although it is worth consideration [55].

\subsection{Role of Colostrum in Ameliorating Chemical Colitis}

Experimental data concerning the role of colostrums in ameliorating chemical colitis have been published during the last years, all of which confirmed the beneficial effect of colostrum and, at the same time, clarified the various mechanisms being responsible for the improvement of experimental colitis (Table 2).

Bodammer et al. showed that prophylactic administration of colostrum was able to improve clinical symptoms and colonic inflammation in a DSS model of colitis, concurrently redistributing immune-regulatory, peripheral and splenic gd TCR+ cells, and CD11b+Gr1+ cells [9]. In a subsequent experimental study, aiming to explore the underlying molecular mechanisms, the same group of investigators found an increased claudin-2 expression in the distal ileum of healthy mice after being fed with colostrum, whereas other tight junction proteins remained unchanged. Interestingly enough, the elevation of claudin-2 was accompanied by neither an increased ion permeability nor an impaired barrier function. In an in situ perfusion model, a $1 \mathrm{~h}$ exposure of the colonic mucosa to colostrum induced increased MRNA levels of barrier-strengthening TGF $\beta$, a fact that might have compensated for the claudin-2 increase and contributed to the barrier strengthening effects of colostrum [56].

Kailash et al. investigated two polyclonal antibodies (AVX-470 and AVX-470m) specific to human TNF isolated from the colostrum of dairy cows that had been previously immunized with TNF, in two models of experimental colitis (DSS and TNBS-induced colitis) [57]. These orally administered antibodies significantly reduced the severity of colitis in a manner comparable with that of oral prednisolone. The authors concluded that the AVX-470 polyclonal anti-TNF antibody has in vitro activity comparable to that of infliximab. One important question concerning this study was related to the absence of breaking-down the administered therapeutic antibodies in the hostile gastric and bowel environment as they were passing through the entire bowel. However, it was found that bovine antibodies from milk or colostrum are suitable for oral delivery by virtue of their stability of digestion in the gastrointestinal tract [58]. Other reports, also, have supported the use of orally administered antibodies from bovine colostrum for the treatment of various disorders [59]. The utilized antibodies were designed to act within the gut lumen against infectious agents. These studies established the safety and efficacy of bovine antibodies, and supported the use of bovine colostrum antibodies as gut-targeted therapeutics. In accordance with the abovementioned studies, the minimally absorbed peptide linaclotide has been approved for the treatment of irritable bowel syndrome [60]. Therefore, bovine colostrum antibodies may form the basis for antibody therapeutics to be locally delivered on the gastrointestinal tract. 
Table 2. Studies on the role of colostrum in experimental colitis.

\begin{tabular}{|c|c|c|c|c|}
\hline Reference & $\begin{array}{c}\text { Chemical } \\
\text { Colitis }\end{array}$ & Experimental Design & Results & Conclusion \\
\hline $\begin{array}{l}\text { Bodammer } \\
\text { et al. } \\
2011 \\
\text { [56] }\end{array}$ & $\begin{array}{l}\text { DSS- } \\
\text { colitis }\end{array}$ & Colostrum vs. BSA vs. water for 2 week & $\begin{array}{l}\text { Improvement of clinical and histological severity. } \\
\text { Redistribution of immune-regulatory, peripheral } \\
\text { and splenic gd TCR+ and CD11b+Gr1+ cells. }\end{array}$ & $\begin{array}{l}\text { Improvement of symptoms } \\
\text { and inflammation. }\end{array}$ \\
\hline $\begin{array}{l}\text { Kailash } \\
\text { et al. } \\
2013 \\
\text { [57] }\end{array}$ & $\begin{array}{l}\text { DSS- } \\
\text { and } \\
\text { TNBS- } \\
\text { Induced } \\
\text { colitis }\end{array}$ & $\begin{array}{l}\text { Isolation of AVX- } 470 \text { and AVX- } 470 \mathrm{~m} \text { from } \\
\text { colostrum of dairy cows immunized with } \\
\text { TNF vs. infliximab }\end{array}$ & $\begin{array}{l}\text { Orally administered AVX-470m reduced } \\
\text { disease severity. } \\
\text { AVX-470 has in vitro activity comparable to that } \\
\text { of infliximab. }\end{array}$ & $\begin{array}{l}\text { Oral administration of this } \\
\text { antibody is effective in treating } \\
\text { mouse models of IBD. }\end{array}$ \\
\hline $\begin{array}{l}\text { Kanwar } \\
\text { et al. } \\
2016 \\
{[61]}\end{array}$ & DSS-colitis & $\begin{array}{l}\text { Oral delivery of bovine milk-derived } \\
\text { Fe-bLF, angiogenin osteopontin, } \\
\text { colostrum, whey protein, Modulen IBD } \\
\text { cis-9,trans-11 conjugated linoleic acid } \\
\text { (CLA)-enriched milk fat }\end{array}$ & $\begin{array}{l}\text { Decrease in cytokine expression. } \\
\text { Fe-bLF, CLA-enriched milk fat, and } \\
\text { CLA-enriched milk fat reduced epithelium } \\
\text { damage, and down-regulated the expression of } \\
\text { proinflammatory cytokines. Myeloperoxidase } \\
\text { activity was lower in mice fed Modulen IBD, OPN, } \\
\text { angiogenin, and Fe-bLF. }\end{array}$ & $\begin{array}{l}\text { Each milk component } \\
\text { attenuated experimental colitis } \\
\text { but with different effectiveness } \\
\text { against specific } \\
\text { disease parameters. }\end{array}$ \\
\hline $\begin{array}{l}\text { Filipescu } \\
\text { et al. } \\
2018 \\
\text { [10] }\end{array}$ & $\begin{array}{c}\text { TNBS- } \\
\text { Induced colitis }\end{array}$ & $\begin{array}{l}\text { Mice received a daily suspension of } \\
\text { bovine colostrum or saline solution for } 21 \\
\text { days before TNBS colitis. }\end{array}$ & $\begin{array}{l}\text { Reduction in BW loss and histological score } \\
\text { compared to CN. } \\
\text { Lower expression of TLR4 IL-1 } \beta \text { IL-8 and IL-10 }\end{array}$ & $\begin{array}{l}\text { Pre-treatment with bovine } \\
\text { colostrum reduces the intestinal } \\
\text { damage and signs of colitis. }\end{array}$ \\
\hline $\begin{array}{l}\text { Spalinger } \\
\text { et al. } \\
2019 \\
\text { [62] }\end{array}$ & $\begin{array}{l}\text { DSS- } \\
\text { colitis and } \\
\text { T-cell transfer colitis: }\end{array}$ & $\begin{array}{l}\text { IMM-124E } \\
\text { a colostrum-based product containing } \\
\text { anti-E.coli-LPS IgG. }\end{array}$ & $\begin{array}{l}\text { Amelioration of DSS colitis and T cell transfer } \\
\text { colitis. Reduction in infiltrating immune cells. } \\
\text { Reduced numbers of effector T helper cells, } \\
\text { increased levels of regulatory T cells. }\end{array}$ & $\begin{array}{l}\text { Oral IMM-124E reduces } \\
\text { intestinal inflammation. }\end{array}$ \\
\hline
\end{tabular}


Kanwar et al., in a DSS model of colitis, used oral delivery of bovine milk-derived iron-saturated lactoferrin (Fe-Blf), angiogenin, osteopontin colostrum whey protein, Modulen IBD, cis-9, trans-11 conjugated linoleic acid (CLA)-enriched milk fat and showed that each milk component attenuated experimental colitis but with a different effectiveness against specific disease parameters. So, they noticed a decrease in cytokine expression in mice fed with the treatment diets compared with DSS mice control group. The Fe-Blf, CLA-enriched milk fat, and diet rich in TGF inhibited intestinal angiogenesis, the CLA-enriched milk fat increased mouse body weight, reduced epithelium damage, and downregulated the expression of proinflammatory cytokines and nitrous oxide. Osteopontin $(\mathrm{OPN})$ lowered the inflammatory score. Myeloperoxidase activity was lower in mice fed with the special diet, OPN, angiogenin, and Fe-Blf [61].

Filipescu et al., in a TNBS model of colitis in rats, noticed that mice pretreated daily with a suspension of bovine colostrum have significantly less intestinal damage and clinical signs of the colitis. They noticed a reduction in body weight loss and histological score of the treated animals as compared to colitis group. The expression levels of TLR4 IL-1 $\beta$ IL-8 and IL-10 were lower in mice receiving bovine colostrum. Interestingly enough, they found no significant changes in bacterial load after the induction of TNBS colitis in colostrum pre-treated mice [10].

In a recently published experimental study, Spalinger et al. using two models of colitis, namely DSS-colitis and T-cell transfer colitis, showed that oral administration of IMM-124E, a colostrum-based product containing anti-E.coli-LPS IgG, reduces intestinal inflammation. More specifically, they noticed a reduction in the serum LPS-binding protein and in flow cytometry, reduced numbers of effector $\mathrm{T}$ helper cells, and increased levels of regulatory T cells. They concluded that IMM-124E might represent a novel therapeutic strategy to induce or maintain remission in chronic colitis [62].

COLOSTRONONI is a new dietary supplement consisting of bovine colostrum and Morinda citrifolia fruit (Noni), the latter being a plant, native to the Indian Ocean, that produces a large number of phytochemicals. This dietary supplement might prevent intestinal inflammation and the development of chronic inflammatory disorders [63]. In an in vitro model of intestinal epithelium, COLOSTRONONI stimulated cell turnover and increased the gene expression of IL-8, two factors being fundamental for the establishment of mechanisms necessary to repair tissue damage [64]. COLOSTRONONI needs to be further explored in clinical trials concerning patients with inflammatory bowel diseases.

In conclusion, the available (mainly experimental) data showed promising results concerning the role of colostrum in IBD. Large clinical studies, in which colostrum should be administered either alone or with other factors, including TGF in an enteral nutrition formula, are needed.

\section{Probiotics in Inflammatory Bowel Disease}

A satisfactory volume of data, including metanalyses, concerning the role of various types of pro- and pre-biotics in patients with active IBD, especially UC, have been recently published, all of which described promising results. However, and despite the positive results achieved in the great majority of the published studies, a permanent echo in the conclusion part of almost all articles is repeated, claiming that " ... despite these promising results, more data derived from large double-blind studies are needed ... " Certainly, the probiotic bacteria used in many studies were not selected on the basis of their immune-modulating properties; rather on the basis of their availability and survival in the upper gastrointestinal tract. Moreover, in some studies, a rather insufficient dosage of probiotics was used. Despite these weaknesses, probiotics could play a rather important role in the treatment of patients with IBD in conjunction with the established medical treatment.

In this section, we shall summarize the data derived from published meta-analyses performed during the last two years (2018 and 2019), regarding the real value of probiotics in the treatment of IBD patients. 


\subsection{Probiotics and IBD Pathophysiology}

It is well-established that gut microbiota composition and metabolism are correlated with the host immune system. Therefore, administration of pro- and pre-biotics could modify the gut microbiota of the patient, leading to a clinical improvement. As mentioned before, a number of in vitro, in vivo and clinical studies in IBD patients evaluating many probiotic formulations, (especially VSL\#3), in active disease and in maintaining remission, have been published [65]. In patients with UC a clinical evidence of efficacy for some specific strains and especially for multi-strain preparations, certainly exists [66]. Knox et al. recently stressed that more encouraging results are emerging as the microbial composition of these probiotics have been optimized in an effort to include bacterial strains showing clear clinical benefit. On the other hand, it is widely accepted that fecal transplantation represents a promising microbiome-modulating treatment in refractory UC, indicating that novel therapies for IBD patients should include a microbiome-modulating approach with a personalized and multidimensional approach [67].

Probiotics exert their beneficial effect through multiple mechanisms, including stimulation of anti-inflammatory and inhibition of pro-inflammatory cytokines, restoration of the intestinal mucosal barrier, antagonistic action on many pathogens, and many others [68] (Table 3). Such mechanisms have been investigated in animal models.

Table 3. Main mechanisms of action of probiotics (modified from Triantafillidis et al. [68]).

\begin{tabular}{|c|c|}
\hline Antimicrobial effect & $\begin{array}{ll}\text { - } & \text { Decreased colonization and invasion by } \\
\text { - } & \text { pathogenic organisms } \\
\text { - } & \text { Prodification of } \mathrm{pH} \\
\text { - } & \text { Block of adhesion sites } \\
\text { - } & \text { Competition for essential nutrients } \\
\text { - } & \text { Degradation of toxin receptor } \\
\end{array}$ \\
\hline Restoration of gut integrity & $\begin{array}{l}\text { - } \quad \text { Restoration of intestinal permeability } \\
\text { - Up-regulation of mucosal barrier function with } \\
\text { up-regulation of tight junction molecules }\end{array}$ \\
\hline Modification of the host immune response & $\begin{array}{l}\text { - } \\
\text { - } \\
\text { - Deduction in proinflammatory cytokine content on plasma } \\
\text { and p65 in the colonic concentration of IL-6, TNF } \alpha \text { NF-kB } \\
\text { - } \quad \text { Reduction in leukocyte recruitment. } \\
\text { - Decrease in colonic MPO activity } \\
\text { - } \quad \text { Expansion of mucosal regulatory cells }\end{array}$ \\
\hline
\end{tabular}

\subsection{Effectiveness of Probiotics in IBD: Results of the Published Meta-Analyses}

There were six metanalyses published during the last two years [13,69-73], the results of which are summarized in Table 4. 
Table 4. Systematic reviews and metaanalyses concerning the role of probiotics in IBD.

\begin{tabular}{|c|c|c|c|c|c|c|}
\hline Reference & $\begin{array}{c}\text { No of RCTs/ } \\
\text { pts }\end{array}$ & Disease & Type of Study & Probiotic Used & Results & Conclusion \\
\hline $\begin{array}{c}\text { Astó } \\
\text { et al. 2019 } \\
\text { [69] }\end{array}$ & $\begin{array}{c}18 \text { studies } \\
1419 \text { patients }\end{array}$ & $\begin{array}{l}\mathrm{UC} \\
\text { active }\end{array}$ & $\begin{array}{c}\text { Probiotics } \\
\text { vs. placebo } \\
\text { vs. active treatment }\end{array}$ & $\begin{array}{l}\text { Bifido- } \\
\text { bacteria }\end{array}$ & $\begin{array}{l}\text { No significant differences for placebo or } \\
\text { mesalazine-controlled studies }\end{array}$ & $\begin{array}{l}\text { Bifidobacteria: Promising } \\
\text { for active UC }\end{array}$ \\
\hline $\begin{array}{l}\text { Peng } \\
\text { et al. } \\
2019 \\
{[70]}\end{array}$ & $\begin{array}{l}27 \text { studies } \\
1942 \text { patients }\end{array}$ & $\begin{array}{l}\text { UC } \\
\text { active }\end{array}$ & $\begin{array}{l}\text { Probiotics with 5-ASA vs. } \\
\text { 5-ASA vs. } \\
\text { Sulfasala- zine }\end{array}$ & & $\begin{array}{l}\text { Remission rate: higher in the group of } \\
\text { probiotics plus mesalazine, vs. mesalazine } \\
\text { Probiotics combined with mesalazine } \\
\text { increased the remission rate in active UC. }\end{array}$ & $\begin{array}{l}\text { Probiotics combined with } \\
\text { 5-ASA increase the } \\
\text { remission rate in active UC }\end{array}$ \\
\hline $\begin{array}{l}\text { Chen et al. } \\
\text { 2019 } \\
\text { [71] }\end{array}$ & $\begin{array}{c}60 \\
\text { studies } \\
4954 \text { patients }\end{array}$ & $\begin{array}{l}\mathrm{UC} \\
\text { active }\end{array}$ & $\begin{array}{l}\text { Bifid probiotic plus } \\
\text { 5-ASA vs. 5-ASA alone }\end{array}$ & $\begin{array}{l}\text { bifid } \\
\text { triple viable } \\
\text { probiotic } \\
\text { (BTV) }\end{array}$ & $\begin{array}{l}\text { BTV plus mesalazine improved the } \\
\text { remission rate and reduced the relapse rate. } \\
\text { Levels of cytokines were reduced and levels } \\
\text { of IL-10, CD3+, CD4+, were increased. }\end{array}$ & $\begin{array}{l}\text { Combination treatment of } \\
\text { BTV with mesalazine } \\
\text { improved active UC. }\end{array}$ \\
\hline $\begin{array}{l}\text { Jia } \\
\text { et al. } \\
2018 \\
{[72]}\end{array}$ & $\begin{array}{c}10 \\
\text { studies } \\
1049 \text { patients }\end{array}$ & IBD & $\begin{array}{l}\text { Probiotics } \\
\text { vs. } \\
\text { Placebo }\end{array}$ & $\begin{array}{l}\text { E coli } \\
\text { Nissle } 1917 \\
\text { and } \\
\text { VSL\#3 }\end{array}$ & $\begin{array}{l}\text { No differences on remission, relapse, and } \\
\text { complication rate between probiotics and } \\
\text { placebo group. } \\
\text { VSL\#3: higher remission rate and lower } \\
\text { relapse rate. }\end{array}$ & $\begin{array}{l}\text { E coli Nissle } 1917 \text { and } \\
\text { VSL\#3: alternative therapy } \\
\text { for } \\
\text { IBD. }\end{array}$ \\
\hline $\begin{array}{l}\text { Ganji-Arjenaki } \\
\text { et al. } \\
2018 \\
{[13]}\end{array}$ & $\begin{array}{l}9 \\
\text { and } \\
18 \text { studies for } \\
\text { CD and UC } \\
\text { respect-tively }\end{array}$ & $\begin{array}{l}\mathrm{UC} \\
\text { and } \\
\mathrm{CD} \\
\text { including } \\
\text { pediatric } \\
\text { population }\end{array}$ & & $\begin{array}{c}\text { VSL\#3 } \\
\text { Lactoba-cillus } \\
\text { Combination of } \\
\text { Saccharo-myces boulardii, } \\
\text { Lactobaci- } \\
\text { llus, and VSL\#3 } \\
\text { In children, combination of } \\
\text { Lactobacillus and VSL\#3 }\end{array}$ & $\begin{array}{l}\text { Analysis of } 9 \text { trials: } \\
\text { Probiotics had not significant effect on CD. } \\
\text { Analysis of } 3 \text { trials in children: } \\
\text { Significant improvement. } \\
\text { Analysis of } 18 \text { trials: } \\
\text { UC: significant effects. } \\
\text { VSL\#3: significant effect Lactobacillus: } \\
\text { significant effect in UC. Combination of } \\
\text { Saccharomyces boulardii, Lactobacillus, and } \\
\text { VSL\#3 in CD: A trend for efficiency } \\
\text { In children: combination of Lactobacillus } \\
\text { with VSL\#3 had significant effect. }\end{array}$ & $\begin{array}{l}\text { Probiotics are beneficial in } \\
\text { IBD and especially in } \\
\text { patients with UC, if they } \\
\text { are administered in } \\
\text { combination. }\end{array}$ \\
\hline $\begin{array}{l}\text { Derwa et al. } \\
2017 \\
{[73]}\end{array}$ & 22 & $\begin{array}{l}\mathrm{UC} \\
\text { or } \\
\mathrm{CD}\end{array}$ & $\begin{array}{l}\text { Probiotics } \\
\text { vs. } \\
\text { placebo } \\
\text { vs. } \\
\text { 5-ASA }\end{array}$ & VSL\#3 & $\begin{array}{c}\text { No benefit of probiotics in active UC } \\
\text { Trials of VSL\#3: clear benefit. } \\
\text { Probiotics equivalent to 5-ASA in } \\
\text { preventing UC relapse. } \\
\text { No benefit of probiotics in active CD, and in } \\
\text { preventing relapses after surgery. }\end{array}$ & $\begin{array}{l}\text { Probiotics are equivalent to } \\
\text { 5-ASA in preventing } \\
\text { relapse of quiescent UC. } \\
\text { Efficacy in CD uncertain. }\end{array}$ \\
\hline
\end{tabular}


The conclusions that we can draw from these metaanalyses could be the following: The administration of probiotics either alone or in combination with mesalazine could increase the rate of clinical remission of patients with UC. No significant differences in the rate of maintenance of remission between patients with UC either receiving probiotics or mesalazine were found, meaning that probiotics are at least equally effective as mesalazine in keeping patients with UC in remission. The VSL\#3 formula achieved the most promising results. No differences in the rate and type of side-effects between the groups of patients receiving probiotics and patients receiving mesalazine, were noticed. At least two meta-analyses confirmed the assumption that probiotics act synergistically with mesalazine significantly increasing the therapeutic benefit. The effectiveness of probiotics in CD patients is weak. However, the combination of Saccharomyces boulardii, Lactobacillus, and VSL\#3 showed a trend for efficiency.

Apart from these metaanalyses, a pilot study comparing probiotics with placebo in their overall oxidant ability and antioxidant response in patients with IBD has recently been published. Ballini et al. showed that the values of oxidative stress and anti-oxidant response observed in the group of patients receiving probiotics for three months were significantly improved, as compared with the group of patients receiving placebo. The authors concluded that the oral administration of specific probiotics could be efficacious and safe in patients with UC [74].

Again, in a very recently published study, Bjarnason et al. found that the administration of a multi-strain probiotic (Symprove ${ }^{\mathrm{TM}}$, Symprove, UK) in patients with IBD was associated with a decreased intestinal inflammation in patients with UC, but not in patients with CD [75]. In another study, concerning the efficacy of different probiotic strains, Alard et al. [76] have tested six strains concerning their ability to improve gut permeability, as well as act as anti-inflammatory agents using in vivo and in vitro models. They found that Bifidobacterium bifidum PI22 strain, while exhibiting significant protective capacities against acute colitis, was slightly efficacious in chronic colitis. On the other hand, Bifidobacterium lactis LA804 strain, although it showed weak efficacy in the acute model of colitis, exhibited a significantly protective action against chronic colitis. Moreover, Lactobacillus helveticus PI5, although it has not shown anti-inflammatory abilities in vitro, has demonstrated a strong epithelial barrier restorative activity, thus improving murine acute colitis. Finally, Lactobacillus salivarius LA307 significantly protected mice against both types of colitis. This study identified four strains having a high potential for the management of IBD.

In conclusion, from the available data it can be assumed that probiotics (especially the VSL\#3) are useful agents for maintaining remissions in patients with pouchitis or active ulcerative colitis, and Bifidobacterium for treating patients with UC in remission [77]. When using probiotics in large doses per day in active disease, the gastroenterologist should bear in mind that this beneficial strategy might be even detrimental for the patient [78]. As previously mentioned, in order to achieve the most optimal results, future work should focus on specific combinations of probiotics that could target specific immune sites in the gut. Moreover, controlled trials with uniform criteria are necessary in order to clarify the efficacy of probiotics, and optimize the clinical results.

\section{Enteral Formulas Supplemented with TGF Used in IBD Patients in Clinical Studies}

During recent years, industry efforts, aiming to preserve the biological activity of some bioactive molecules in end products, resulted in the production of food containing TGF $\beta$ [6-8]. Recently, more enteral formulas supplemented with TGF $\beta 2$ appeared in the market. One of them (Santactiv Digest powder) is a polymeric diet rich in TGF $\beta 2$ from colostrum, supplemented with probiotics (Bacillus coagulans) and $n-3$ fatty acids. The main nutritional values of this formula per $60 \mathrm{~g}$ powder are as follows: Energy: $300 \mathrm{kcal}$, lipids $13 \mathrm{~g}$, carbohydrates $32 \mathrm{~g}$, proteins $13 \mathrm{~g}$, fiber $0.1 \mathrm{~g}$ vitamins A, C, E, B complex, D3, K1, trace elements, L-glutamine $2 \mathrm{~g}$, colostrum $0.6 \mathrm{~g}$ and probiotics $5.0 \mathrm{mld}$. The $60 \mathrm{~g}$ of powder should be diluted in $190 \mathrm{~mL}$ of fresh water and consumed in about half an hour. Each meal offers $300 \mathrm{kcal}$. It is not suitable to be used as source of nutrition. The dosage recommended is two 
sachets of $60 \mathrm{~g}$ per day in the active phase of $\mathrm{CD}$, and one sachet of $60 \mathrm{~g}$ per day as a nutritional support during the remission phase [79].

There is a considerable speculation concerning the mode of action of these formulas in IBD. It seems that in CD endogenous healing pathways mediated by TGF $\beta$ are inhibited because mucosal inflammatory cells express Smad7, the endogenous intracellular inhibitor of TGF $\alpha$ signaling [80]. It seems unlikely that enteral feeds containing TFG $\beta$ exert their therapeutic effect by means of direct anti-inflammatory effects, although TGF $\beta$ may promote mucosal healing in synergy with changes in mucosal bacterial populations as a result of the change in the diet. Antigen exclusion and changes in bacterial flora seem to be the most important [81]. An important anti-inflammatory effect of TGF $\beta$ is the promotion and generation of FOXP3-positive regulatory T cells in the intestinal compartment [82].

A relatively unanswered question is related to the ability of TGF $\beta$ to pass the whole digestive tract without degradation by the digestive enzymes. According to Beattle et al. [83], a survey of the TGF $\beta$ content of twenty milk-based preparations demonstrated that its presence depends on the source of milk protein and processing conditions. It seems that casein itself may inhibit the enzymatic degradation of TGF $\beta$ by the duodenal and enteric juice [84].

So far, very few studies concerning the role of a diet rich in TGF $\beta$ in improving experimental colitis, have been published. Oz et al. investigated the effect of an orally administered diet containing TGF $\beta 2$ on intestinal injury and immune responses in an IL-10 knockout mouse model of colitis. At the end of the 8th week mice fed with the diet rich in TGF- $\beta 2$ significantly increased their body weight and hematocrite, and decreased the levels of serum amyloid A and TNF $\alpha$, compared to the control diet group. Concerning histology, a lower score of severity was noticed in the TGF $\beta 2$ group as compared with the control group [85]. In an interesting study, treatment with TGF $\beta 2$ of rats with experimentally methotrexare-induced intestinal mucositis prevented mucosal-injury, enhanced p-ERK and $\beta$-catenin induced enterocyte proliferation, inhibited enterocyte apoptosis and improved intestinal recovery [86].

As far as it concerns the clinical efficacy of enteral nutrition rich in TGF $\beta$ in IBD patients, very few data are available. These studies are analyzed subsequently. Ferreira et al. assessed the effects of nutrition supplementation with and without TGF $\beta 2$ on inflammatory, endoscopic, histopathologic, and nutrition parameters in 38 patients with active CD. Patients were divided into three groups: group 1 (patients with nutrition orientation), group 2 (nutrition orientation and normal nutrition), and group 3 (nutrition orientation and nutritional supplement with TGF $\beta 2$ ) for 3 months. At the end of the study, the CDAI was reduced in groups 2 and 3, while in group 3 a reduction in C-Reactive Protein (CRP) levels and an improvement in histologic findings were observed. They concluded that, despite the improvement in nutrition and inflammatory patterns, only those patients receiving TGF 32 -enriched formula showed an improvement in histologic parameters and a reduction in CRP levels [87].

Beaupel et al. evaluated the effect of preoperative administration of exclusive TGF $\beta 2$ in decreasing postoperative complications after surgery for complicated ileocolonic CD (35 high vs. 21 low-risk patients). The result showed that the discontinuation of steroids in preoperative TGF $\beta 2$ group was feasible in $62.5 \%$. No significant differences in the complication rates between the two groups were observed. Thus, the preoperative administration of TGF $\beta 2$ diet is feasible and beneficial in high-risk patients with complicated $C D$, as it could effectively reduce the postoperative morbidity, although the results should be confirmed in large randomized controlled trials [88].

Davanço et al. described the effect of a diet supplement containing whey proteins and TGF $\beta$ on the body composition of 42 consecutive patients with $\mathrm{CD}$. They noticed that patients supplemented with this regime showed an increase in their lean body mass, as compared with the non-supplemented group. They concluded that whey protein intake supplemented with TGF $\beta$ can improve the Lean Body Mass, while concurrently reducing the fat percentage [89].

In another study, 29 adult patients with active CD received a special diet supplemented with TGF $\beta$ as an exclusive diet for 4 weeks at a dose of $50 \mathrm{~g} \times 5 / \mathrm{d}$. Clinical improvement was noticed in $69 \%$ of the patients. All nutritional parameters were improved. Patients stopped losing weight and the score of general well-being increased. No change of the situation or worsening was noticed in 9 patients (31\%). 
The results suggested that this diet could be effective in inducing remission in a proportion of adult patients with mild CD [6]. Regarding the long-term efficacy of TGF $\beta$ rich diet in maintaining remission, Triantafillidis et al. compared the results of the administration of a diet rich in TGF $\beta$ with those of mesalazine in a group of patients with $C D$ in remission. Patients were assigned to receive either two meals $(2 \times 50 \mathrm{~g})$ of the special diet plus two regular meals per day or mesalazine $(800 \mathrm{mg}$ three times a day) for six months. At the end of the trial, $69 \%$ of patients in the special diet arm continued to be in remission compared with $60 \%$ of those receiving mesalazine (no significant differences). The mean time from remission to relapse was 103 days versus 123 days, respectively [7]. However, when interpreting these results, one should bear in mind the current knowledge of the lack of efficacy of mesalazine in maintaining remission in Crohn's disease patients [90]. A quite interesting finding of this study was the increase in the levels of HDL and the decrease in the levels of LDL in patients receiving the special diet. The role of dysfunctional HDL in cytokine induction and inflammation seems to be quite important, as HDL can modulate LDL oxidation and LDL-induced cytokine production and inflammation [91]. Dysfunctional HDL has been identified in animal models and humans with chronic inflammatory diseases. It seems that the anti-inflammatory properties of HDL may be at least as important as the levels of HDL-cholesterol. The pathophysiological consequences of the administration of a diet rich in TGF $\beta$ needs further exploration, as the levels of HDL and LDL before and after treatment of IBD patients could constitute a useful index of inflammatory activity.

\section{Other Nutritional Compounds}

\subsection{Short Chain Fatty Acids (SCFAs)}

SCFAs are fatty acids with less than six carbons and including five acids, namely acetate, formic, propionate, butyrate, and valeric acid. SCFAs are secondary metabolites produced through the fermentation of dietary substrates (proteins, peptides, resistant starches, and undigested fibers) by the gut microbioma. SCFAs represent the exclusive energy source for the intestinal epithelial cells. The production of these fatty acids is influenced by certain parameters, including host nutrition, and the existence and concentration of specific commensal bacteria [92]. For example, propionate and acetate are produced by Firmicutes and Bacteroidetes phylum respectively, through the lactate and succinate pathway [93]. In addition, the production of butyrate, acetate, and propionate, possess different ratios in different sites of the intestinal tract, as well as different physiological activities; e.g., propionate and acetate could be present in both large and small intestines, while butyrate is mainly present in cecum and left colon [94]. SCFAs may be absorbed by passive diffusion, although energetic uptake by the intestinal epithelial cells could also be succeeded via special substrate transporters [95].

SCFAs support and maintain the intestinal homeostasis and the gut barrier function having direct or indirect effects on intestinal epithelial cells, including proliferation, differentiation, and gene expression. SCFAs exhibit modulating effects on immune cells (e.g., T cells, especially Tregs, neutrophils, and macrophages). In fact, the SCFAs can affect cytokine production and migration, cytolytic activity, and epigenetic modulation. SCFAs may signal through cell surface G-protein coupled receptors to activate signaling cascades that control immune functions [96]. Butyrate, probably the most important SCFA, influences both the adaptive and the innate immunity, regulating the activation of regulatory $\mathrm{T}$ cells, and decreasing the activation of NF-KB. Butyrate, also, increases the mucus production and the rearrangement of tight junction proteins [97].

In patients with IBD gut SCFAs are reduced, although the results of the relevant studies could be characterized as conflicting. In a recently published systematic review and metaanalysis, Zhuang et al. found significant alterations of SCFAs in IBD patients; e.g., in patients with active and inactive ulcerative colitis inverse SCFA alterations [98]. The significance of these fatty acids in the pathogenesis of IBD is further supported by the fact according to which bacteria in mucosa and feces of patients with IBD producing SCFAs are reduced. IBD patients show reduced levels of dominant SCFAs-producing 
bacteria (like Faecalibacterium prausnitzii and Roseburia intestinalis) in intestinal mucosa and feces, and lower levels of SCFAs compared to healthy controls [99].

It is well-established that intestinal inflammatory responses are modulated by the gut microbiome. The importance of microbiota in controlling inflammation is shown when a bowel segment is excluded from the fecal stream (diversion colitis/pouchitis) [100]. IBD patients show dysbiosis and loss of microbiome diversity, and the associated alterations in SCFA levels might be restored by fecal microbiota transplantation obtained from healthy donors [101].

In conclusion, SCFAs represent important dietary metabolites that might be useful in the treatment of patients with IBD. The use of prebiotics and probiotics and fiber-rich diets may improve the clinical condition of patients with IBD by improving the levels of SCFAs and especially butyrate, in the bowel lumen.

\subsection{Flavonoids}

Flavonoid compounds are a large family of hydroxylated polyphenolic molecules abundant in plants, including vegetables and fruits, which are the major dietary sources of these compounds for humans, along with wine and tea. Flavonoids are becoming very popular as they have many health-promoting and disease-preventive effects. Most interest has been directed towards the antioxidant activity of flavonoids, evidencing a remarkable free-radical scavenging capacity. Flavonoids have many other biological properties, including anti-inflammatory, antiviral, anticancer, and neuroprotective activities [102]. Key mechanisms relate to their anti-inflammatory and antioxidant properties, as well as their ability to modulate gut microbiota, have been recently described [103]. Go to:

Several studies asserted the anti-IBD effects of Citrus fruits and their flavonoids, thus providing evidence favoring their role in the prevention and treatment of IBD. In a prospective study of preillness diet in newly diagnosed patients with Crohn's disease, Octoratou et al. found that foods decreasing the risk of acquiring Crohn's disease on logistic regression analysis, were citrus fruits [104]. Other studies considering the use of plants containing flavonoids in patients with IBD have shown that these plants may actually induce clinical response and, to a lesser degree, clinical remission [105]. A pilot clinical study performed in patients with ulcerative colitis refractory to 5-ASA and/or azathioprine has revealed beneficial results [106].

In conclusion, it could be argued that flavonoids could potentially be used as an effective treatment in patients with IBD. Their anti-inflammatory effects and the mechanisms of action have been confirmed in experimental models being similar to those of the drugs currently used in patients with IBD, including biologic agents [107]. On the other hand, fruits and vegetables represent a very safe and without risk source of flavonoids making them a cheap and widely available therapeutic modality. Further clinical studies should be performed in order to elucidate the efficacy of various flavonoids in patients with IBD.

\subsection{Bioactive Peptides}

It is well-known that the digestibility of dietary proteins is higher than $90 \%$. However, a certain amount of luminal proteins may escape digestion in the small intestine and be transferred into the large intestine. It has been estimated that between 6 and $18 \mathrm{~g}$ of protein reach the colon serving as a nitrogenous substrate for the microbiota activity in the large intestine. The origin of protein (animal or plant) influences the nature and quantity of amino acids delivered in the large bowel lumen. Increased protein intake could result in gut bacterial dysbiosis by altering the microbiota composition and the mucosal immune system. Bacterial metabolites derived from amino acids, such as $\mathrm{H}_{2} \mathrm{~S}$ and ammonia, could have a positive or negative impact on the intestinal epithelium with some of them being detrimental and some others beneficial. 
Epidemiological evidence indicates that the consumption of high animal protein is associated with an increased risk of IBD [108]. Food components could modulate DNA methylation and a number of epigenetic mechanisms, thus predisposing to IBD development [109].

A lot of published data confirmed that peptides originating from different food sources have antiinflammatory, antioxidant and immunomodulatory properties [110]. For instance, amino acids derived from dietary proteins display beneficial effects helping the macromolecule synthesis in the inflamed bowel mucosa. However, an excessive amount of dietary proteins may result in an increased production of deleterious bacterial metabolites causing the inhibition of colonic epithelial cell proliferation, and increasing intestinal permeability [111]. The impact of the high protein diet on the gut microbiota and colonic epithelium might be amplified in patients with a compromised barrier function, such as patients with IBD.

Bioactive peptides that could modulate the intestinal cytokine milieu in normal people might be beneficial for keeping patients with IBD in remission and preventing relapses, although they are not able to restore the altered mucosal cytokine profile in patients with active IBD [78]. Therefore, dietary peptides and amino acids could be useful as alternative treatments in IBD [112]. The exact role of dietary peptides and amino acids should be further investigated in order to develop patient-tailored diets for IBD patients.

\section{Conclusions}

The available data indicate that EN enriched in TGF $\beta$, apart from restoring the impaired nutritional status, could also modulate intestinal immune responses, thus positively affecting the inflammatory bowel processes. This type of EN could be characterized as a supporting and/or primary therapy aiming to induce and/or maintain remission. These formulas enriched with colostrum and probiotics of a special amount and consistency might be proved of benefit in patients with IBD in the near future. In our opinion, it is important not to underestimate the role of nutrition as supportive care in patients with CD. Further well-designed large trials with enteral formulas containing TGF $\beta$, colostrum, probiotics and other nutritional compounds are necessary in order to improve the results of EN.

Author Contributions: Conceptualization: J.K.T.; Methodology: J.K.T., M.T.; Data curation: E.T., J.K.T.; Writing—original draft preparation: J.K.T., E.T.; Writing—review and editing: J.K.T., M.T., E.T.; All authors have read and agreed to the published version of the manuscript.

Funding: This research received no external funding.

Conflicts of Interest: The authors declare no conflict of interest.

\section{References}

1. Di Caro, S.; Fragkos, K.C.; Keetarut, K.; Koo, F.H.; Sebepos-Rogers, G.; Saravanapavan, H.; Barragry, J.; Rogers, J.; Mehta, S.J.; Rahman, F. Enteral nutrition in adult Crohn's disease: Toward a paradigm shift. Nutrients 2019, 11, 2222. [CrossRef]

2. Swaminath, A.; Feathers, A.; Ananthakrishnan, A.N.; Falzon, L.; Li Ferry, S. Systematic review with meta-analysis: Enteral nutrition therapy for the induction of remission in paediatric Crohn's disease. Aliment. Pharmacol. Ther. 2017, 46, 645-656. [CrossRef]

3. Forbes, A.; Escher, J.; Hebuterne, X.; Kłe, S.; Krznaric, Z.; Schneider, S.; Shamir, R.; Stardelova, K.; Wierdsma, N.; Wiskin, A.E.; et al. ESPEN guideline: Clinical nutrition in inflammatory bowel disease. Clin. Nutr. 2017, 36, e321-e347. [CrossRef]

4. Triantafillidis, J.K.; Vagianos, C.; Papalois, A.E. The role of enteral nutrition in patients with inflammatory bowel disease: Current aspects. Biomed. Res. Int. 2015, 2015, 197167. [CrossRef]

5. Yun, S.M.; Kim, S.H.; Kim, E.H. The molecular mechanism of Transforming Growth Factor- $\beta$ signaling for intestinal fibrosis: A mini-review. Front. Pharmacol. 2019, 10, 162. [CrossRef] [PubMed]

6. Triantafillidis, J.K.; Stamataki, A.; Gikas, A.; Sklavaina, M.; Mylonaki, M.; Georgopoulos, F.; Mastragelis, A.; Cheracakis, P. Beneficial effect of a polymeric feed, rich in TGF- $\alpha$, on adult patients with active Crohn's disease: A pilot study. Ann. Gastroenterol. 2006, 19, 66-71. 
7. Triantafillidis, J.K.; Stamataki, A.; Karagianni, V.; Gikas, A.; Malgarinos, G. Maintenance treatment of Crohn's disease with a polymeric feed rich in TGF- $\beta$. Ann. Gastroenterol. 2010, 23, 113-118.

8. Hartman, C.; Berkowitz, D.; Weiss, B.; Shaoul, R.; Adiv, O.E.; Shapira, R.; Fradkin, A.; Wilschanski, M.; Tamir, A. Nutritional supplementation with polymeric diet enriched with transforming growth factor-beta 2 for children with Crohn's disease. Isr. Med. Ass J. 2008, 10, 503-507. [PubMed]

9. Bodammer, P.; Maletzki, C.; Waitz, G.; Emmrich, J. Prophylactic application of bovine colostrum ameliorates murine colitis via Induction of immunoregulatory cells. J. Nutr. 2011, 141, 1056-1061. [CrossRef]

10. Filipescu, I.E.; Leonardi, L.; Menchetti, L.; Guelfi, G.; Traina, G.; Casagrande-Proietti, P.; Piro, F.; Quattrone, A.; Barbato, O.; Brecchia, G. Preventive effects of bovine colostrums supplementation in TNBS-induced colitis in mice. PLOS ONE 2018, 13, e0202929. [CrossRef]

11. Abraham, B.; Quigley, E.M.M. Antibiotics and probiotics in inflammatory bowel disease: When to use them? Front. Gastroenterol. 2020, 11, 62-69. [CrossRef] [PubMed]

12. Coqueiro, A.Y.; Raizel, R.; Bonvini, A.; Tirapegui, J.; Rogero, M.M. Probiotics for inflammatory bowel diseases: A promising adjuvant treatment. Int. J. Food Sci. Nutr. 2019, 70, 20-29. [CrossRef] [PubMed]

13. Ganji-Arjenaki, M.; Rafieian-Kopaei, M. Probiotics are a good choice in remission of inflammatory bowel diseases: A metaanalysis and systematic review. J. Cell Physiol. 2018, 233, 2091-2103. [CrossRef] [PubMed]

14. Sanjabi, S.; Oh, S.A.; Li, M.O. Regulation of the immune response by TGF-b: From conception to autoimmunity and infection. Cold Spring Harb. Perspect. Biol. 2017, 9, a022236. [CrossRef] [PubMed]

15. Gordon, K.J.; Blobe, G.C. Role of transforming growth factor- $\beta$ superfamily signaling pathways in human disease. Biochim. Biophys. Acta 2008, 1782, 197-228. [CrossRef]

16. Vallance, B.A.; Gunawan, M.I.; Hewlett, B.; Bercik, P.; Van Kampen, C.; Galeazzi, F.; Sime, P.J.; Gauldie, J.; Collins, S.M. TGF-beta1 gene transfer to the mouse colon leads to intestinal fibrosis. Am. J. Physiol. Gastrointest Liver Physiol. 2005, 289, G116-G128. [CrossRef]

17. Ihara, S.; Hirata, Y.; Koike, K. TGF- $\beta$ in inflammatory bowel disease: A key regulator of immune cells, epithelium, and the intestinal microbiota. J. Gastroenterol. 2017, 52, 777-787. [CrossRef]

18. Massagué, J. TGF $\beta$ signalling in context. Nat. Rev. Mol. Cell Biol. 2012, 13, 616-630. [CrossRef]

19. Letterio, J.J.; Roberts, A.B. Regulation of immune responses by TGF-beta. Ann. Rev. Immunol. 1998, 16, $137-161$. [CrossRef]

20. Massagué, J.; Xi, Q. TGF- $\beta$ control of stem cell differentiation genes. FEBS Lett. 2012, 586, $1953-1958$. [CrossRef]

21. Li, M.O.; Wan, Y.Y.; Sanjabi, S.; Robertson, A.K.L.; Flavell, R.A. Transforming growth factor- $\beta$ regulation of immune responses. Ann. Rev. Immunol. 2006, 24, 99-146. [CrossRef]

22. Kubiczkova, L.; Sedlarikova, L.; Hajek, R.; Sevcikova, S. TGF- $\beta$-An excellent servant but a bad master. J. Transl. Med. 2012, 10, 183. [CrossRef] [PubMed]

23. Smythies, L.E.; Sellers, M.; Clements, R.H.; Mosteller-Barnum, M.; Meng, G.; Benjamin, W.H.; Orenstein, J.M.; Smith, D. Human intestinal macrophages display profound inflammatory anergy despite avid phagocytic and bacteriocidal activity. J. Clin. Investig. 2005, 115, 66-75. [CrossRef] [PubMed]

24. Järvinen, K.M.; Westfall, J.E.; Seppo, M.S.; James, A.K.; Tsuang, A.J.; Feustel, P.; Sampson, H.A.; Berin, C. Role of maternal elimination diets and human milk IgA in the development of cow's milk allergy in the infants. Clin. Exp. Allergy 2014, 44, 69-78. [CrossRef] [PubMed]

25. Hanahan, D.; Weinberg, R.A. The hallmarks of cancer. Cell 2000, 100, 57-70. [CrossRef]

26. Babyatsky, M.W.; Rossiter, G.; Podolsky, D.K. Expression of transforming growth factors alpha and beta in colonic mucosa in inflammatory bowel disease. Gastroenterology 1996, 110, 975-984. [CrossRef]

27. Katuri, V.; Tang, Y.; Li, C.; Jogunoori, W.; Deng, C.X.; Rashid, A.; Sidawy, A.N.; Evans, S.; Reddy, E.P.; Mishra, B.; et al. Critical interactions between TGF-beta signaling/ELF, and E-cadherin/beta-catenin mediated tumor suppression. Oncogene 2006, 25, 1871-1886. [CrossRef]

28. di Mola, F.F.; Friess, H.; Scheuren, A.; Di Sebastiano, P.; Graber, H.; Egger, B.; Zimmermann, A.; Korc, M.; Büchler, M.W. Transforming growth factor-betas and their signaling receptors are coexpressed in Crohn's disease. Ann. Surg. 1999, 229, 67-75. [CrossRef]

29. Rieder, F.; Fiocchi, C. Intestinal fibrosis in IBD-a dynamic, multifactorial process. Nat. Rev. Gastroenterol. Hepatol. 2009, 6, 228-235. [CrossRef]

30. Massague, J.; Seoane, J.; Wotton, D. Smad transcription factors. Genes Dev. 2005, 19, 2783-2810. [CrossRef] 
31. Sedda, S.; Marafini, I.; Dinallo, V.; Di Fusco, D.; Monteleone, G. The TGF- $\beta /$ Smad System in IBD Pathogenesis. Inflamm. Bowel Dis. 2015, 21, 2921-2925. [CrossRef] [PubMed]

32. Boirivant, M.; Pallone, F.; Di Giacinto, C.; Fina, D.; Monteleone, I.; Marinaro, M.; Caruso, R.; Colantoni, A.; Palmieri, G.; Sanchez, M.; et al. Inhibition of Smad7 with a specific antisense oligonucleotide facilitates TGF-beta1-mediated suppression of colitis. Gastroenterology 2006, 131, 1786-1798. [CrossRef] [PubMed]

33. Monteleone, G.; Fantini, M.C.; Onali, S.; Zorzi, F.; Sancesario, G.; Bernardini, S.; Calabrese, E.; Viti, F.; Monteleone, I.; Biancone, L.; et al. Phase I clinical trial of Smad7 knockdown using antisense oligonucleotide in patients with active Crohn's disease. Mol. Ther. 2012, 20, 870-876. [CrossRef] [PubMed]

34. Monteleone, G.; Neurath, M.F.; Ardizzone, S.; Di Sabatino, A.; Fantini, M.C.; Castiglione, F.; Scribano, M.L.; Armuzzi, A.; Caprioli, F.; Sturniolo, G.C.; et al. Mongersen, an oral SMAD7 antisense oligonucleotide, and Crohn's disease. N. Engl. J. Med. 2015, 372, 1104-1113. [CrossRef] [PubMed]

35. Ulloa, L.; Doody, J.; Massague, J. Inhibition of transforming growth factor-beta/SMAD signalling by the interferon-gamma/STAT pathway. Nature 1999, 397, 710-713. [CrossRef] [PubMed]

36. Kotlarz, D.; Marquardt, B.; Barøy, T.; Lee, W.S.; Konnikova, L.; Hollizeck, S.; Magg, T.; Lehle, A.S.; Walz, C.; Borggraefe, I.; et al. Human TGF- $\beta 1$ deficiency causes severe inflammatory bowel disease and encephalopathy. Nat. Genet. 2018, 50, 344-348. [CrossRef]

37. Stelwagen, K.; Carpenter, E.; Haigh, B.; Hodgkinson, A.; Wheeler, T.T. Immune components of bovine colostrum and milk. J. Anim. Sci. 2009, 87, 3-9. [CrossRef]

38. Xu, M.; Kim, H.; Kim, H. Effect of dietary bovine colostrum on the responses of immune cells to stimulation with bacterial lipopolysaccharide. Arch. Pharm. Res. 2014, 37, 494-500. [CrossRef]

39. Donnet-Hughes, A.; Duc, N.; Serrant, P.; Vidal, K.; Schiffrin, E.J. Bioactive molecules in milk and their role in health and disease: The role of transforming growth factor-beta. Immunol. Cell Biol. 2000, 78, 74-79. [CrossRef]

40. Munblit, D.; Abrol, P.; Sheth, S.; Chow, L.Y.; Khaleva, E.; Asmanov, A.; Lauriola, S.; Padovani, E.M.; Comberiati, P.; Boner, A.L.; et al. Levels of growth factors and IgA in the colostrum of women from Burundi and italy. Nutrients 2018, 10, 1216. [CrossRef]

41. Castellote, C.; Casillas, R.; Ramírez-Santana, C.; Pérez-Cano, F.J.; Castell, M.; Moretones, M.G.; López-Sabater, M.C.; Franch, A. Premature delivery influences the immunological composition of colostrum and transitional and mature human milk. J. Nutr. 2011, 110, 1181-1187. [CrossRef] [PubMed]

42. Krissansen, G.W. Emerging health properties of whey proteins and their clinical implications. J. Am. Coll. Nutr. 2007, 26, 713S-723S. [CrossRef] [PubMed]

43. Buccigrossi, V.; de Marco, G.; Bruzzese, E.; Ombrato, L.; Bracale, I.; Polito, G.; Guarino, A. Lactoferrin induces concentration-dependent functional modulation of intestinal proliferation and differentiation. Pediatr. Res. 2007, 61, 410-414. [CrossRef] [PubMed]

44. Norrby, K.; Mattsby-Baltzer, I.; Innocenti, M.; Tuneberg, S. Orally administered bovine lactoferrin systemically inhibits VEGF165-mediated angiogenesis in the rat. Int. J. Cancer 2001, 91, 236-240. [CrossRef]

45. Hill, D.R.; Newburg, D.S. Clinical applications of bioactive milk components. Nutr. Rev. 2015, 73, 463-476. [CrossRef] [PubMed]

46. Aakko, J.; Kumar, H.; Rautava, S.; Wise, A.; Autran, C.; Bode, L.; Isolauri, E.; Salminen, S. Human milk oligosaccharide categories define the microbiota composition in human colostrum. Benef. Microbes 2017, 8, 563-567. [CrossRef]

47. Hanson, L.A. Comparative immunological studies of the immune globulins of human milk and of blood serum. Int. Arch. Allergy Appl. Immunol. 1961, 18, 241-267. [CrossRef]

48. Walker, A. Breast milk as the gold standard for protective nutrients. J. Pediatr. 2010, 156 (Suppl. 2), S3-S7. [CrossRef]

49. Cairangzhuoma, Y.M.; Muranishi, H.; Inagaki, M.; Uchida, K.; Yamashita, K.; Saito, S.; Yabe, T.; Kanamaru, Y. Skimmed, sterilized, and concentrated bovine late colostrum promotes both prevention and recovery from intestinal tissue damage in mice. J. Dairy Sci. 2013, 96, 1347-1355. [CrossRef]

50. Lund, P.; Sangild, P.T.; Aunsholt, L.; Hartmann, B.; Holst, J.J.; Mortensen, J.; Mortensen, P.B.; Jeppesen, P.B. Randomised controlled trial of colostrum to improve intestinal function in patients with short bowel syndrome. Eur. J. Clin. Nutr. 2012, 66, 1059-1065. [CrossRef] 
51. Moøller, H.K.; Thymann, T.; Fink, L.N.; Frokiaer, H.; Kvistgaard, A.S.; Sangild, P.T. Bovine colostrum is superior to enriched formulas in stimulating intestinal function and necrotising enterocolitis resistance in preterm pigs. Br. J. Nutr. 2011, 105, 44-53. [CrossRef] [PubMed]

52. Otto, W.; Najnigier, B.; Stelmasiak, T.; Robins-Browne, R.M. Randomized control trials using a tablet formulation of hyperimmune bovine colostrum to prevent diarrhea caused by enterotoxigenic Escherichia coli in volunteers. Scand. J. Gastroenterol. 2011, 46, 862-868. [CrossRef] [PubMed]

53. Støy, A.C.F.; Heegaard, P.M.H.; Thymann, T.; Bjerre, M.; Skovgaard, K.; Boye, M.; Stoll, B.; Mette Schmidt, M.; Bent, B.; Jensen, B.B.; et al. Bovine colostrum improves intestinal function following formula-induced gut inflammation in preterm pigs. Clin. Nutr. 2014, 33, 322-329. [CrossRef]

54. Bodammer, P.; Zirzow, E.; Klammt, S.; Maletzki, C.; Kerkhoff, C. Alteration of DSS-mediated immune cell redistribution in murine colitis by oral colostral immunoglobulin. BioMedCentral Immunol. 2013, 14, 10. [CrossRef] [PubMed]

55. Khan, Z.; Macdonald, C.; Wicks, A.C.; Holt, M.P.; Floyd, D.; Ghosh, S.; Wright, N.A.; Playford, R.J. Use of the 'nutriceutical', bovine colostrum, for the treatment of distal colitis: Results from an initial study. Aliment. Pharm. Ther. 2002, 16, 1917-1922. [CrossRef]

56. Bodammer, P.; Kerkhoff, C.; Maletzki, C.; Lamprecht, G. Bovine colostrum increases pore-forming claudin-2 protein expression but paradoxically not ion permeability possibly by a change of the intestinal cytokine milieu. PLoS ONE 2013, 8, e64210. [CrossRef]

57. Bhol, K.C.; Tracey, D.E.; Lemos, B.R.; Lyng, G.D.; Erlich, E.C.; Keane, D.M.; Quesenberry, M.S.; Holdorf, A.D.; Schlehuber, L.D.; Clark, S.A.; et al. AVX-470: A novel oral anti-TNF antibody with therapeutic potential in inflammatory bowel disease. Inflamm. Bowel Dis. 2013, 19, 2273-2281. [CrossRef]

58. Roos, N.; Mahe, S.; Benamouzig, R.; Sick, H.; Rautureau, J.; Tomé, D. 15N-labeled immunoglobulins from bovine colostrum are partially resistant to digestion in human intestine. J. Nutr. 1995, 125, 1238-1244. [CrossRef]

59. Greenberg, P.D.; Cello, J.P. Treatment of severe diarrhea caused by Cryptosporidium parvum with oral bovine immunoglobulin concentrate in patients with AIDS. J. Acquir. Immune Defic. Syndr. Hum. Retrovirol. 1996, 13, 348-354. [CrossRef]

60. Vazquez-Roque, M.I.; Bouras, E.P. Linaclotide, novel therapy for the treatment of chronic idiopathic constipation and constipation-predominant irritable bowel syndrome. Adv. Ther. 2013, 30, 203-211. [CrossRef]

61. Kanwar, J.R.; Kanwar, R.K.; Stathopoulos, S.; Haggarty, N.W.; MacGibbon, A.K.H.; Palmao, K.P.; Roy, K.; Rowan, A.; Krissansen, G.W. Comparative activities of milk components in reversing chronic colitis. J. Dairy Sci. 2016, 99, 2488-2501. [CrossRef] [PubMed]

62. Spalinger, M.R.; Atrott, K.; Baebler, K.M.; Melhem, H.; Peres, D.R.; Lalazar, G.; Rogler, G.; Scharl, M.; Frey-Wagner, I. Administration of the hyper-immune bovine colostrum extract IMM-124E ameliorates experimental murine colitis. J. Crohns Colitis 2019, 13, 785-797. [CrossRef] [PubMed]

63. Cardani, D. Colostro Noni: Administration effects on epithelial cells turn-over, inflammatory events and integrity of intestinal mucosa junctional systems. Minerva Gastroenterol. Dietol. 2014, 60, 71-78. [PubMed]

64. Duranti, S.; Mancabelli, L.; Mancino, W.; Anzalone, R.; Longhi, G.; Statello, R.; Carnevali, L.; Sgoifo, A.; Bernasconi, S.; Turroni, F.; et al. Exploring the effects of COLOSTRONONI on the mammalian gut microbiota composition. PLoS ONE 2019, 14, e0217609. [CrossRef] [PubMed]

65. Sivamaruthi, B.S. A comprehensive review on clinical outcome of probiotic and synbiotic therapy for inflammatory bowel diseases. Asian Pac. J. Trop. Biomed. 2018, 8, 179-186. [CrossRef]

66. Guandalini, S.; Sansotta, N. Probiotics in the treatment of inflammatory bowel disease. Adv. Exp. Med. Biol. 2019, 1125, 101-107. [CrossRef]

67. Knox, N.C.; Forbes, J.D.; van Domselaar, G.; Bernstein, C.N. The gut microbiome as a target for IBD treatment: Are we there yet? Curr. Treat. Opt. Gastroenterol. 2019, 17, 115-126. [CrossRef]

68. Triantafillidis, J.K.; Georgopoulos, F.; Merikas, E. The role of pre- and probiotics in the treatment of Inflammatory Bowel Disease. J. Microb. Biochem. Technol. 2011, S1, 5. [CrossRef]

69. Astó, E.; Méndez, I.; Audivert, S.; Farran-Codina, A.; Espadaler, J. The efficacy of probiotics, prebiotic inulin-type fructans, and synbiotics in human ulcerative colitis: A systematic review and meta-analysis. Nutrients 2019, 11, 293. [CrossRef] 
70. Peng, L.; Zhong, Y.; Wang, A.; Jiang, Z. Probiotics combined with aminosalicylic acid affiliates remission of ulcerative colitis: A meta-analysis of randomized controlled trial. Biosci. Rep. 2019, 39, BSR20180943. [CrossRef]

71. Chen, M.Y.; Qiu, Z.W.; Tang, H.M.; Zhuang, K.H.; Cai, Q.Q.; Chen, X.; Li, H.B. Efficacy and safety of bifid triple viable plus aminosalicylic acid for the treatment of ulcerative colitis: A systematic review and meta-analysis. Medicine 2019, 98, e17955. [CrossRef] [PubMed]

72. Jia, K.; Tong, X.; Wang, R. The clinical effects of probiotics for inflammatory bowel disease: A meta-analysis. Medicine 2018, 97, e13792. [CrossRef] [PubMed]

73. Derwa, Y.; Gracie, D.J.; Hamlin, P.J.; Ford, A.C. Systematic review with meta-analysis: The efficacy of probiotics in inflammatory bowel disease. Aliment. Pharm. Ther. 2017, 46, 389-400. [CrossRef] [PubMed]

74. Ballini, A.; Santacroce, L.; Cantore, S.; Bottalico, L.; Dipalma, G.; Topi, S.; Saini, R.; De Vito, D.; Inchingolo, F. Probiotics efficacy on oxidative stress values in inflammatory bowel disease: A randomized double-blinded placebo-controlled pilot study. Endocr. Metab. Immune Disord. Drug Targets 2019, 19, 373-381. [CrossRef]

75. Bjarnason, I.; Sission, G.; Hayee, B. A randomised, double-blind, placebo-controlled trial of a multi-strain probiotic in patients with asymptomatic ulcerative colitis and Crohn's disease. Inflammopharmacology 2019, 27, 465-473. [CrossRef]

76. Alard, J.; Peucelle, V.; Boutillier, D.; Breton, J.; Kuylle, S.; Pot, B.; Holowacz, S.; Grangette, C. New probiotic strains for inflammatory bowel disease management identified by combining in vitro and in vivo approaches. Benef. Microbes 2018, 9, 317-331. [CrossRef]

77. Koretz, R.L. Probiotics in gastroenterology: How pro is the evidence in adults? Am. J. Gastroenterol. 2018, 113, 1125-1136. [CrossRef]

78. Fernández-Tomé, S.; Marin, A.C.; Moreno, L.O.; Baldan-Martin, M.; Mora-Gutiérrez, I.; Lanas-Gimeno, A.; Moreno-Monteagudo, J.A.; Santander, C.; Sánchez, B.; Chaparro, M.; et al. Immunomodulatory effect of gut microbiota-derived bioactive peptides on human immune system from healthy controls and patients with Inflammatory Bowel Disease. Nutrients 2019, 11, 2605. [CrossRef]

79. Urlep, D.; Benedik, E.; Brecelj, J.; Orel, R. Partial enteral nutrition induces clinical and endoscopic remission in active pediatric Crohn's disease: Results of a prospective cohort study. Eur. J. Pediatr. 2019. [CrossRef]

80. MacDonald, T.T.; Di Sabatino, A.; Gordon, J.N. Immunopathogenesis of Crohn's disease. JPEN J. Parenter. Enteral Nutr. 2005, 29, S118-S124. [CrossRef]

81. Bannerjee, K.; Camacho-Hubner, C.; Babinska, K.; Dryhurst, K.M.; Edwards, R.; Savage, M.O.; Sanderson, I.R.; Croft, N.M. Antiinflammatory and growth-stimulating effects precede nutritional restitution during enteral feeding in Crohn disease. J. Pediatr. Gastroenterol. Nutr. 2004, 38, 270-275. [CrossRef] [PubMed]

82. Ruemmele, F.M.; Garnier-Lengline, H. Transforming Growth Factor and Intestinal Inflammation: The Role of Nutrition; Nestle Nutrition Institute Workshop Series; Nestec Ltd.: Basel, Switzerland, 2013; Volume 77, pp. 91-98.

83. Beattle, R.M.; Schiffrin, E.J.; Donnet-Hughes, A.; Huggett, A.C.; Domizio, P.; MacDonald, T.T.; Walker-Smith, J.A. Polymeric nutrition as the primary therapy in children with small bowel Crohn's disease. Aliment. Pharmacol. Ther. 1994, 8, 609-615. [CrossRef] [PubMed]

84. Woodman, A.C.; Claerk, P.; Watanapa, P.; Vesey, D.; Deprez, P.H.; Williamson, R.C.; Calam, J. Effect of luminal growth factor preservation on intestinal growth. Lancet 1993, 341, 843-847. [CrossRef]

85. Oz, H.S.; Ray, M.; Chen, T.S.; McClain, C.J. Efficacy of a transforming growth factor beta 2 containing nutritional support formula in a murine model of inflammatory bowel disease. J. Am. Coll. Nutr. 2004, 23, 220-226. [CrossRef] [PubMed]

86. Ben-Lulu, S.; Pollak, Y.; Mogilner, J.; Bejar, J.; Coran, A.G.; Sukhotnik, I. Dietary transforming growth factor-beta2 (TGF- $\beta 2$ ) supplementation reduces methotrexate-induced intestinal mucosal injury in a rat. PLoS ONE 2012, 7, e45221. [CrossRef] [PubMed]

87. Ferreira, T.M.R.; Albuquerque, A.; Cancela Penna, F.G.; Rosa, R.M.; Toulson, M.I.; Correia, D.; Barbosa, A.J.B.; Cunha, A.S.; Ferrari, M.L.A. Effect of oral nutrition supplements and TGF- $\beta 2$ on nutrition and inflammatory patterns in patients with active Crohn's disease. Nutr. Clin. Pract. 2019. [CrossRef] [PubMed]

88. Beaupel, N.; Brouquet, A.; Abdalla, S.; Carbonnel, F.; Penna, C.; Benoist, S. Preoperative oral polymeric diet enriched with transforming growth factor-beta 2 (Modulen) could decrease postoperative morbidity after surgery for complicated ileocolonic Crohn's disease. Scand. J. Gastroenterol. 2017, 52, 5-10. [CrossRef] 
89. Davanço, T.; Oya, V.; Saddy Rodrigues Coy, C.; Leal, F.R.; Ayrizono Ma de, L.S.; Sgarbieri, V.C.; dos Santos Vilela, M.M.; Lomazi, E.A. Nutritional supplementation assessment with whey proteins and TGF- $\beta$ in patients with Crohn's disease. Nutr. Hosp. 2012, 27, 1286-1292. [CrossRef]

90. Gomollón, F.; Dignass, A.; Annese, V.; Tilg, H.; Van Assche, G.; Lindsay, J.O.; Peyrin-Biroulet, L.; Cullen, G.J.; Daperno, M.; Kucharzik, T.; et al. 3rd European evidence-based consensus on the diagnosis and management of Crohn's disease 2016: Part 1: Diagnosis and Medical Management. J. Crohns Colitis 2017, 11, 3-25. [CrossRef]

91. Tabet, F.; Rye, K.A. High-density lipoproteins, inflammation and oxidative stress. Clin. Sci. (Lond.) 2009, 116, 87-98. [CrossRef]

92. Canfora, E.E.; Jocken, J.W.; Blaak, E.E. Short-chain fatty acids in control of body weight and insulin sensitivity. Nat. Rev. Endocrinol. 2015, 11, 577-591. [CrossRef] [PubMed]

93. Louis, P.; Hold, G.L.; Flint, H.J. The gut microbiota, bacterial metabolites and colorectal cancer. Nat. Rev. Microbiol. 2014, 12, 661-672. [CrossRef] [PubMed]

94. Vogt, S.L.; Pena-Diaz, J.; Finlay, B.B. Chemical communication in the gut: Effects of microbiota-generated metabolites on gastrointestinal bacterial pathogens. Anaerobe 2015, 34, 106-115. [CrossRef] [PubMed]

95. Brown, A.J.; Goldsworthy, S.M.; Barnes, A.A.; Eilert, M.M.; Tcheang, L.; Daniels, D. The orphan G protein-coupled receptors. J. Biol. Chem. 2003, 278, 11312-11319. [CrossRef] [PubMed]

96. Parada Venegas, D.; De la Fuente, M.K.; Landskron, G.; González, M.J.; Quera, R.; Dijkstra, G.; Harmsen, H.J.M.; Faber, K.N.; Hermoso, M.A. Short chain fatty acids (SCFAS)-mediated gut epithelial and immune regulation and its relevance for inflammatory bowel diseases. Front. Immunol. 2019, 10, 277, Erratum in: Front. Immunol. 2019, 10, 1486. [CrossRef] [PubMed]

97. Silva, J.P.B.; Navegantes-Lima, K.C.; Oliveira, A.L.B.; Rodrigues, D.V.S.; Gaspar, S.L.F.; Monteiro, V.V.S.; Moura, D.P.; Monteiro, M.C. Protective mechanisms of butyrate on Inflammatory Bowel Disease. Curr. Pharm. Des. 2018, 24, 4154-4166. [CrossRef] [PubMed]

98. Zhuang, X.; Li, T.; Li, M.; Huang, S.; Qiu, Y.; Feng, R.; Zhang, S.; Chen, M.; Xiong, L.; Zeng, Z. Systematic review and meta-analysis: Short-chain fatty acid characterization in patients with inflammatory bowel disease. Inflamm. Bowel Dis. 2019, 25, 1751-1763. [CrossRef] [PubMed]

99. Takahashi, K.; Nishida, A.; Fujimoto, T.; Fujii, M.; Shioya, M.; Imaeda, H.; Inatomi, O.; Bamba, S.; Sugimoto, M.; Andoh, A. Reduced abundance of butyrate-producing bacteria species in the fecal microbial community in crohn's disease. Digestion 2016, 93, 59-65. [CrossRef]

100. Tominaga, K.; Kamimura, K.; Takahashi, K.; Yokoyama, J.; Yamagiwa, S.; Terai, S. Diversion colitis and pouchitis: A mini-review. World J. Gastroenterol. 2018, 24, 1734-1747. [CrossRef]

101. Paramsothy, S.; Paramsothy, R.; Rubin, D.T.; Kamm, M.A.; Kaakoush, N.O.; Mitchell, H.M.; Castaño-Rodríguez, N. Faecal microbiota transplantation for inflammatory bowel disease: A systematic review and meta-analysis. J. Crohns Colitis 2017, 11, 1180-1199. [CrossRef]

102. Salaritabar, A.; Darvishi, B.; Hadjiakhoondi, F.; Manayi, A.; Sureda, A.; Nabavi, S.F.; Fitzpatrick, L.R.; Nabavi, M.S.; Bishayee, A. Therapeutic potential of flavonoids in inflammatory bowel disease: A comprehensive review. World J. Gastroenterol. 2017, 23, 5097-5114. [CrossRef] [PubMed]

103. Musumeci, L.; Maugeri, A.; Cirmi, S.; Lombardo, G.E.; Russo, C.; Gangemi, S.G.; Navarra, M. Citrus fruits and their flavonoids in inflammatory bowel disease: An overview. Nat. Prod. Res. 2020, 34, 122-136. [CrossRef] [PubMed]

104. Octoratou, M.; Merikas, E.; Malgarinos, G.; Stanciu, C.; Triantafillidis, J.K. A prospective study of pre-illness diet in newly diagnosed patients with Crohn's disease. Rev. Med. Chir. Soc. Med. Nat. Iasi. 2012, 116, 40-49. [PubMed]

105. Vezza, T.; Rodríguez-Nogales, A.; Algieri, F.; Utrilla, M.P.; Rodriguez-Cabezas, M.E.; Galvez, J. Flavonoids in Inflammatory Bowel Disease: A Review. Nutrients 2016, 8, 211. [CrossRef]

106. Dryden, G.W.; Lam, A.; Beatty, K.; Qazzaz, H.H.; McClain, C.J. A pilot study to evaluate the safety and efficacy of an oral dose of (-)-epigallocatechin-3-gallate-rich polyphenon e in patients with mild to moderate ulcerative colitis. Inflamm. Bowel Dis. 2013, 19, 1904-1912. [CrossRef]

107. Valatas, V.; Vakas, M.; Kolios, G. The value of experimental models of colitis in predicting efficacy of biological therapies for inflammatory bowel diseases. Am. J. Physiol. Gastrointest Liver Physiol. 2013, 305, G763-G785. [CrossRef]

108. Lewis, J.D. The role of diet in Inflammatory Bowel Disease. Gastroenterol. Hepatol. (N. Y.) 2016, 12, 51-53. 
109. Castro, F.; de Souza, H.S.P. Dietary composition and effects in inflammatory bowel disease. Nutrients 2019, 11, 1398. [CrossRef]

110. Fernández-Tomé, S.; Hernández-Ledesma, B.; Chaparro, M.; Indiano-Romacho, P.; Bernardo, D.; Gisbert, J.P. Role of food proteins and bioactive peptides in inflammatory bowel disease. Trends Food Sci. Technol. 2019, 88, 194-206. [CrossRef]

111. Vidal-Lletjós, S.; Beaumont, M.; Tomé, D.; Benamouzig, R.; Blachier, F.; Lan, A. Dietary protein and amino acid supplementation in inflammatory bowel disease course: What impact on the colonic mucosa? Nutrients 2017, 9, 310. [CrossRef]

112. Zhang, H.; Hu, C.A.A.; Kovacs-Nolan, J.; Mine, Y. Bioactive dietary peptides and amino acids in inflammatory bowel disease. Amino Acid 2015, 47, 2127-2141. [CrossRef] [PubMed]

(C) 2020 by the authors. Licensee MDPI, Basel, Switzerland. This article is an open access article distributed under the terms and conditions of the Creative Commons Attribution (CC BY) license (http://creativecommons.org/licenses/by/4.0/). 